\title{
Selective Protein-Protein Interactions Driven by a Phenylalanine Interface
}

Nicholas C. Yoder and Krishna Kumar*

Department of Chemistry, Tufts University, Medford, MA 02155

J. Am. Chem. Soc.

\section{Supporting Information}

Complete Ref. (1a) from main text:

Gavin, A. C.; Bosche, M.; Krause, R.; Grandi, P.; Marzioch, M.; Bauer, A.; Schultz, J.; Rick, J. M.; Michon, A. M.; Cruciat, C. M.; Remor, M.; Hofert, C.; Schelder, M.;

Brajenovic, M.; Ruffner, H.; Merino, A.; Klein, K.; Hudak, M.; Dickson, D.; Rudi, T.; Gnau, V.; Bauch, A.; Bastuck, S.; Huhse, B.; Leutwein, C.; Heurtier, M. A.; Copley, R. R.; Edelmann, A.; Querfurth, E.; Rybin, V.; Drewes, G.; Raida, M.; Bouwmeester, T.; Bork, P.; Seraphin, B.; Kuster, B.; Neubauer, G.; Superti-Furga, G. Nature 2002, 415, 141-147.

\section{Peptide synthesis}

For $t$-Boc chemistry, resin was a standard Merrifield resin with a methylbenzylhydrylamine (MBHA) linker (Novabiochem).

For Fmoc chemistry, 30 minute coupling cycles were programmed on the Advanced ChemTech $348 \Omega$ Synthesizer. For each cycle, 5-20 molar equivalents (relative to $\mathrm{NH}_{2}$ equiv.) of amino acid were coupled for 30 minutes with 0.9 equivalents (relative to amino acid) of diisopropylcarbodiimide (DIC) and one equivalent (relative to amino acid) of hydroxybenzatriazole (HOBt). DIC, $\mathrm{HOBt}$, and the Rink Amide resin used were from Advanced ChemTech, Louisville, KY.

Amino acids were from Advanced ChemTech, Novabiochem, and Fisher. Side chain protecting groups for amino acids in $t$-Boc synthesis were: $\operatorname{Arg}(\operatorname{Tos}), \operatorname{Asp}(\mathrm{Bzl})$, Asn(Xan), Cys(4-MeBzl), Glu(Bzl), Gln(Xan), His(Dnp), Lys(2-Cl-Z), Ser(Bzl), $\operatorname{Trp}(\mathrm{For})$, Tyr(2-Br-Z). Side chain protecting groups for amino acids in Fmoc synthesis were: Cys(Trt), Glu(t-Bu), Gln(Trt), Lys(Boc), Ser(tBu), Trp(Boc). $N$-terminal acetylation was effected using $10 \% \mathrm{v} / \mathrm{v}$ acetic anhydride in DMF with 1 equiv. of diisopropylethylamine relative to on resin $\mathrm{NH}_{2}$ equivalents.

Peptides synthesized by $t$-Boc chemistry were cleaved using high HF conditions (90\% anhydrous $\mathrm{HF} / 10 \%$ anisole at $0{ }^{\circ} \mathrm{C}$ for $1.5 \mathrm{hrs}$ ). Peptides synthesized by Fmoc chemistry were removed from the resin with excess of 5:10:85 triisopropylsilane (TIPS):trifluoroacetic acid (TFA):methylene chloride (v/v/v). The resulting solution was concentrated by rotary evaporation and the side chain protecting groups removed from 
the peptide by addition of 3:3:5:89 TIPS: $\mathrm{H}_{2} \mathrm{O}$ :ethanedithiol:TFA (v/v/v/v) and stirring for $2 \mathrm{hrs}$. In both cleavage protocols, peptides were precipitated using excess cold diethyl ether, retained on a porous glass filter, and recovered with $10 \%$ acetic acid.

All reagents were from Sigma unless stated otherwise and were used without further purification.

Peptides $\mathbf{P}$ and $\mathbf{P 2}$ were synthesized using manual $t$-Boc synthesis while $\mathbf{P 1}$ and A1 were synthesized using both manual $t$-Boc and automated Fmoc methods in independent syntheses.

\section{Analytical Ultracentrifugation}

Data were collected at the peptide concentrations indicated, at $10^{\circ} \mathrm{C}$ in $10 \mathrm{mM}$ phosphate $\mathrm{pH} 7.4$ with $137 \mathrm{mM} \mathrm{NaCl}$ and $2.7 \mathrm{mM} \mathrm{KCl}$. Reported number of helices are averages of fitted runs at three speeds. ${ }^{1}$ In most cases, the fits consistently showed nonrandom residuals (as would be expected from the non-integral oligomerization states); the exception was $\mathbf{P 2}$ which at $10 \mu \mathrm{M}$ consistently showed random residuals.

Table S1. Average concentration-dependent molecular weights with oligomerization states, and thermal denaturation temperatures for phenylalanine core peptides.

\begin{tabular}{|ccccc|}
\hline & \multicolumn{4}{c|}{$\mathrm{MW}_{\text {approx }}$ (no. of helices) } \\
Peptide & $5 \mu \mathrm{M}$ & $10 \mu \mathrm{M}$ & $30 \mu \mathrm{M}$ & $\mathrm{Tm}\left({ }^{\circ} \mathrm{C}\right)^{a}$ \\
\hline P & $7962(2.08)$ & $9754(2.55)$ & $10655(2.78)$ & 49 \\
$(\mathbf{P 1})_{2}$ & $17236(4.26)$ & $18044(4.45)$ & $16599(4.10)$ & 73 \\
$(\mathbf{A 1})_{2}$ & $7587(2.04)$ & $10523(2.84)$ & $10574(2.85)$ & 65 \\
P2 & $12003(2.83)$ & $12523(2.96)$ & $11988(2.83)$ & 47 \\
P1-A1 & -- & -- & -- & $64^{b}$ \\
\hline
\end{tabular}

${ }^{a}$ For thermal denaturation: $[\mathbf{P}]=10 \mu \mathrm{M} ;\left[(\mathbf{P 1})_{2}\right]=\left[(\mathbf{A ~ 1})_{2}\right]=5 \mu \mathrm{M}$; all samples are in $10 \mathrm{mM}$ phosphate $\mathrm{pH} 7.4,137 \mathrm{mM} \mathrm{NaCl}, 2.7 \mathrm{mM} \mathrm{KCl} .{ }^{b}$ Thermal denaturation was not reversible $(\sim 70 \%$ of the signal was recovered after cooling to room temperature). 
Figure S1. Representative AUC-SE trace for peptide P. Conditions as above, with $30 \mu \mathrm{M}$ peptide, rotor speed $=35000 \mathrm{rpm}$. Fitted $\mathrm{M}=10645$. For two helices, $\mathrm{MW}_{\text {calc }}=7660$; for three helices, $\mathrm{MW}_{\text {calc }}$ $=11490$.
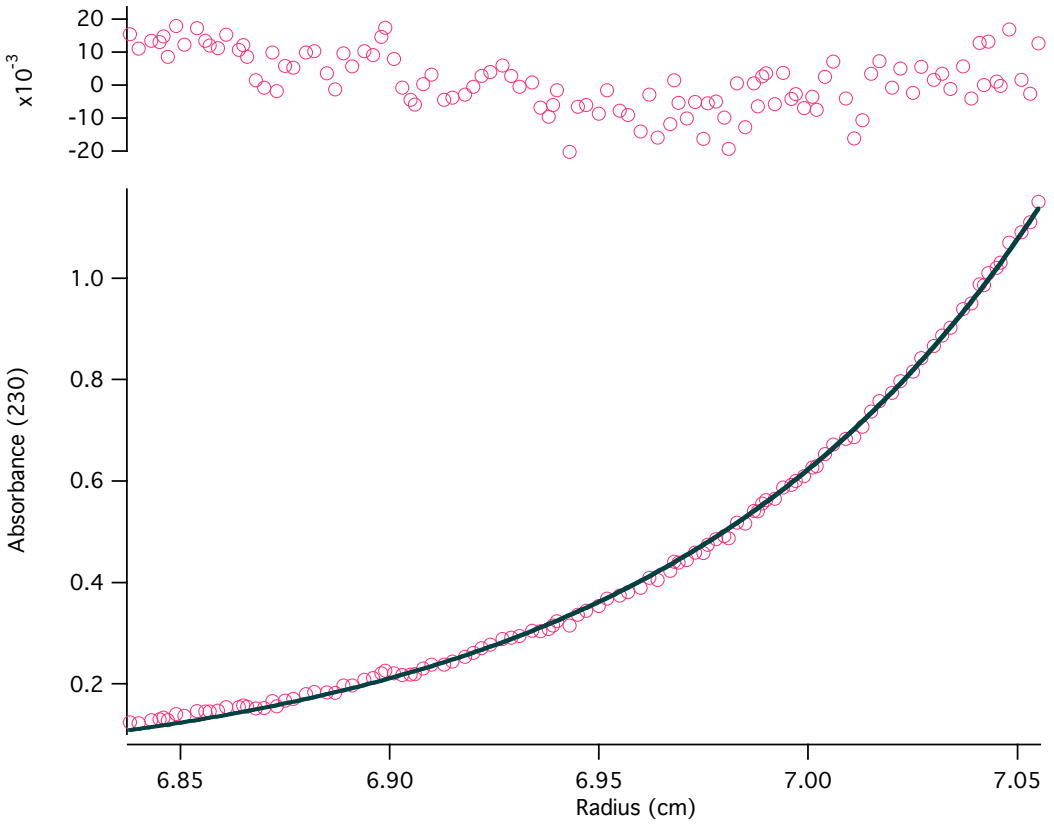

Figure S2. Representative AUC-SE trace from peptide $(\mathbf{P 1})_{2}$. Conditions as above, with peptide concentration $=5 \mu \mathrm{M}$, rotor speed $=45000 \mathrm{rpm}$. Fitted $\mathrm{M}=16960$. For four helices, $\mathrm{MW}_{\text {calc }}=16196$
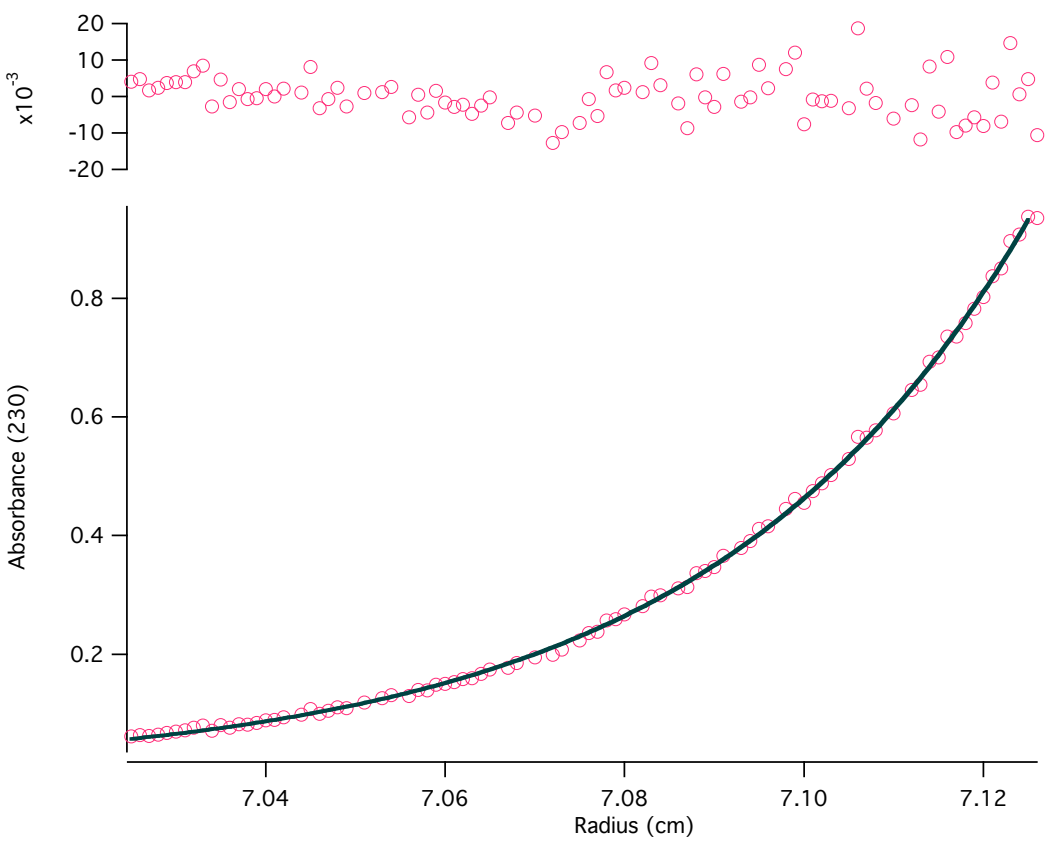
Figure S3. Representative AUC-SE trace from peptide $(\mathbf{A 1})_{2}$. Conditions as above, with peptide concentration $=30 \mu \mathrm{M}$, rotor speed $=40000 \mathrm{rpm}$. Fitted $\mathrm{M}=9788$. For two helices, $\mathrm{MW}_{\text {calc }}=7418$; for four helices, $\mathrm{MW}_{\text {calc }}=14836$
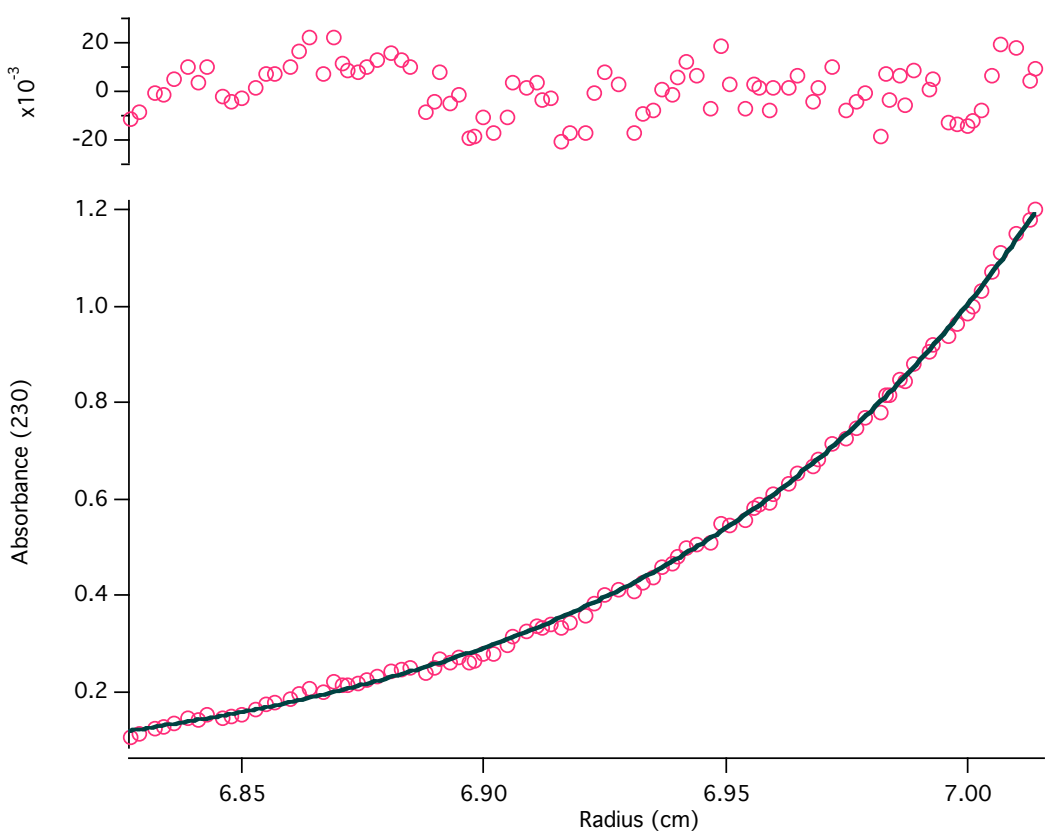


\section{Thermodynamic cycle analysis}

Shown below is a thermodynamic cycle used for calculating $\Delta G_{\text {spec }}$, the free energy of specificity for formation of homodimers $(\mathbf{P 1})_{2}$ and $(\mathbf{A 1})_{2} . K_{\text {folding }}$ refers to the equilibrium constant between folded and unfolded forms of the peptides. We assume that the peptides are completely folded under the conditions of the exchange experiment. This assumption is supported by the CD data. $K_{\text {random }}$ is the equilibrium constant for a purely random combination of peptides and is assumed to equal $2 .^{2}$

$$
\begin{aligned}
& 0.5(\mathbf{P 1})_{2} \mathrm{U}+0.5(\mathbf{A} 1)_{2} \mathrm{U} \stackrel{\mathrm{K}_{\text {random }}=2}{\rightleftharpoons}(\mathbf{P} 1-\mathbf{A} 1)^{\mathrm{U}} \\
& \left\|\mathrm{K}_{\text {folding }}^{(\mathbf{P 1})} \quad\right\| \mathrm{K}_{\text {folding }}^{(\mathbf{A} 1)} \quad \| \mathrm{K}_{\text {folding }}^{\text {P1-A1 }} \\
& 0.5(\mathbf{P 1})_{2}{ }^{\mathrm{F}}+0.5(\mathbf{A 1})_{2}{ }^{\mathrm{F}} \stackrel{\mathrm{K}_{\text {redox }}}{=}(\mathbf{P 1 - A 1})^{\mathrm{F}} \\
& \left\|\mathrm{K}_{n \text {-helices }}^{(\mathbf{P} 1)} \quad\right\| \mathrm{K}_{n \text {-helices }}^{(\mathbf{A} 1)} \\
& n^{-1} \cdot(\mathbf{P} 1)_{2}{ }^{\mathrm{F}}+n^{-1} \cdot(\mathbf{A} 1)_{2}{ }^{\mathrm{F}} \\
& \mathrm{K}_{\text {redox }}=\frac{\left[(\mathbf{P} 1-\mathbf{A} \mathbf{1})^{\mathrm{F}}\right]}{\left[(\mathbf{A} \mathbf{1})_{2}{ }^{\mathrm{F}}\right]^{0.5}\left[(\mathbf{P} \mathbf{1})_{2}{ }^{\mathrm{F}}\right]^{0.5}} \\
& \Delta G_{\text {spec }} \text { (for homodimers) }=-\left\{\Delta G_{\text {redox }}+R T \text { In } 2\right\}
\end{aligned}
$$

$(\mathbf{P 1})_{2}$ and $(\mathbf{A 1})_{2}$ were measured by HPLC of exchange products. Peaks corresponding to each peptide product were manually integrated using the Hitachi D-7000 software package. Under the conditions of the experiment, the molar extinction coefficient of $(\mathbf{A 1})_{2}$ was slightly larger than that of $(\mathbf{P 1})_{2}\left(\varepsilon_{\mathbf{A} \mathbf{1}} / \varepsilon_{\mathbf{P 1}}=1.18\right)$. This was verified and measured by injection of quantitatively reduced P1-A1. With correction for the difference in molar extinction coefficient, the integration values were used directly to compute $K_{\text {redox }}$. The value of $-1.5 \mathrm{kcal} / \mathrm{mol}$ given in the text is an average of four experiments with a standard deviation of $0.08 \mathrm{kcal} / \mathrm{mol}$. 


\section{Mass Spectra}

Figure S4. MALDI TOF-MS of purified peptide $\mathbf{P}\left(\right.$ calc. $=3833.5[\mathrm{M}+\mathrm{H}]^{+}$, observed 3824.1).

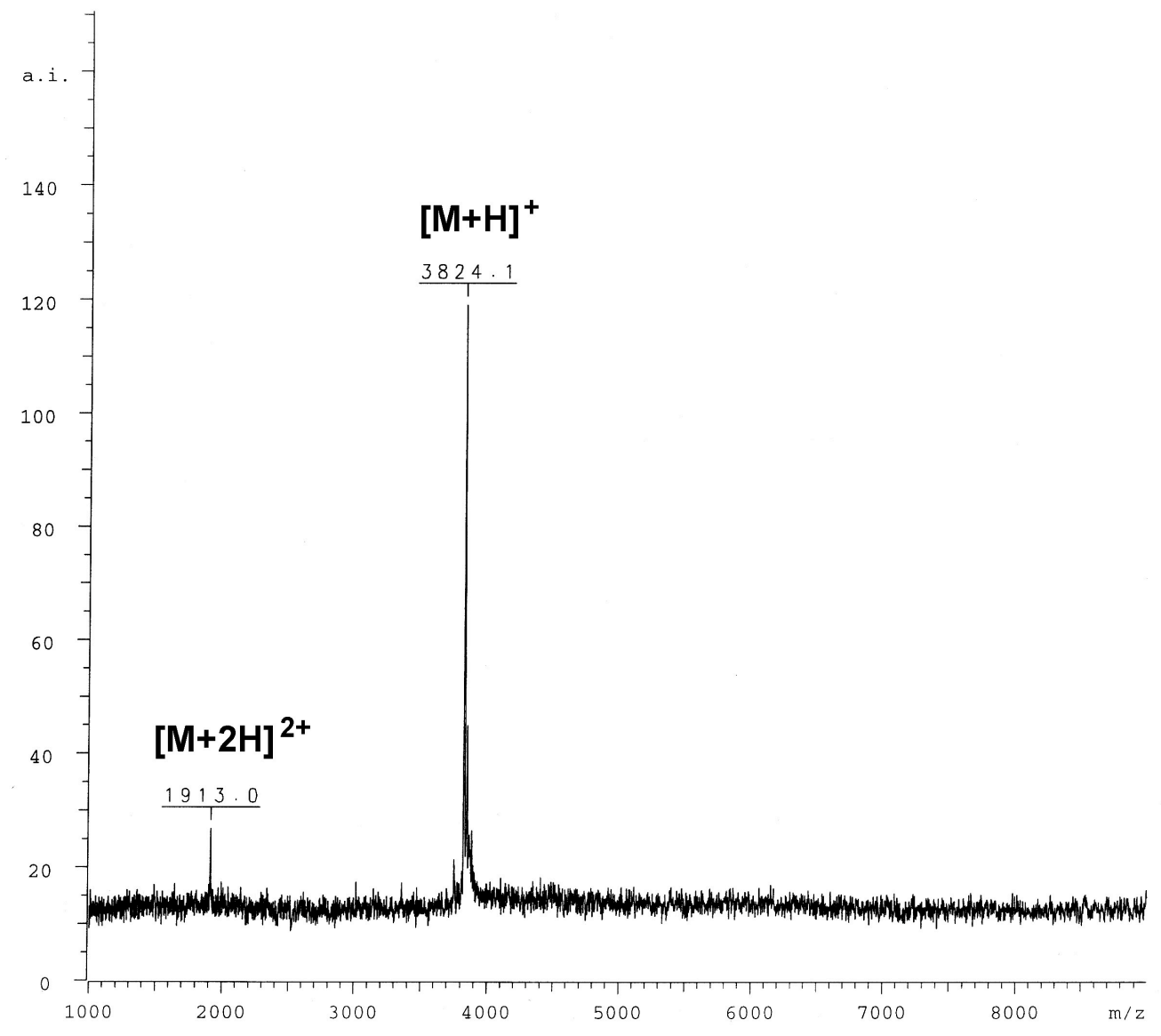


Figure S5. MALDI TOF-MS of purified peptide $(\mathbf{P 1})_{2}\left(\right.$ calc. $=8098.3[\mathrm{M}+\mathrm{H}]^{+}$, observed 8101.6).

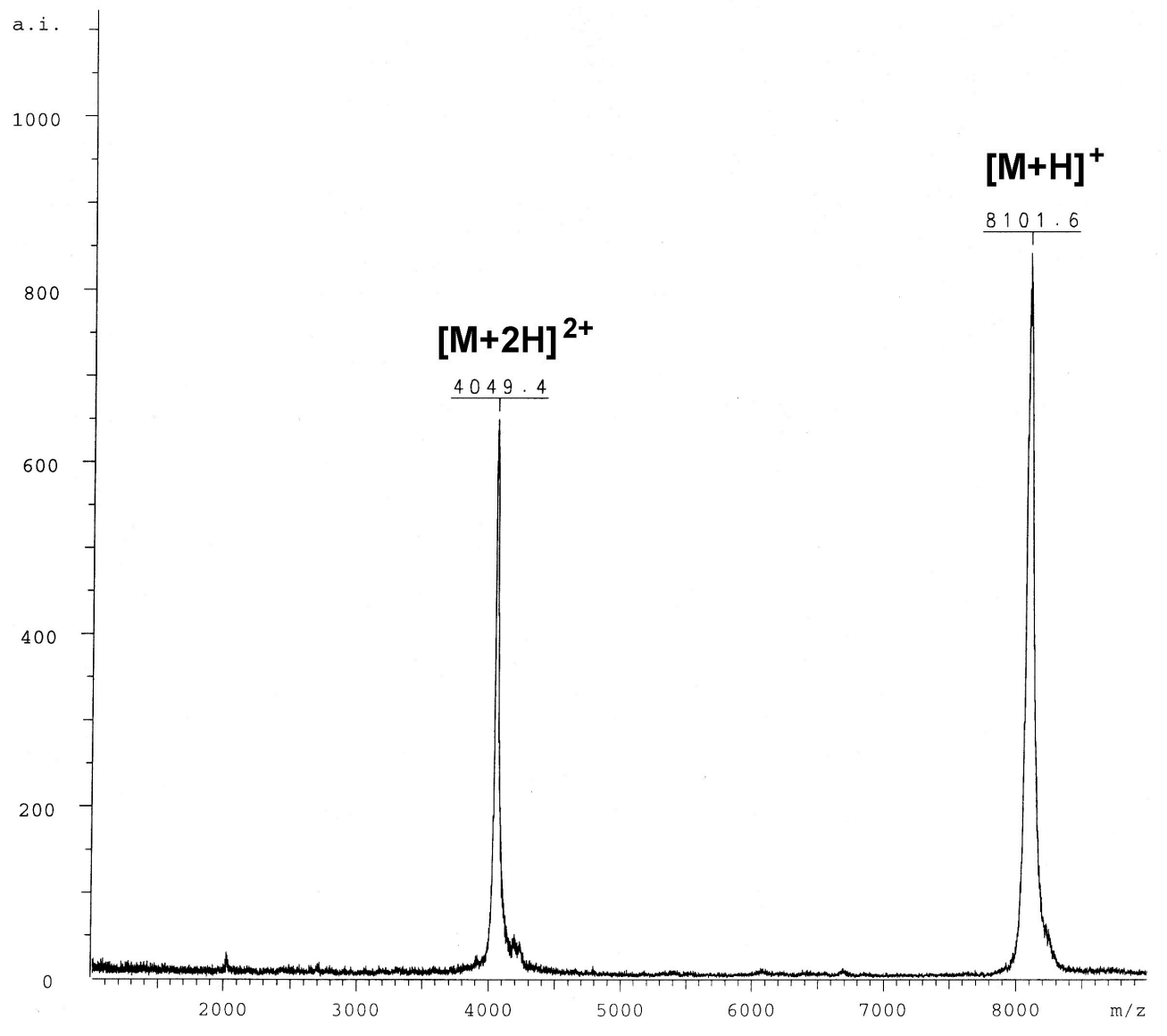


Figure S6. MALDI TOF-MS of purified peptide $(\mathbf{A 1})_{2}\left(\right.$ calc. $=7417.7\left[\mathrm{M}^{+}\right]$, observed 7409.3).

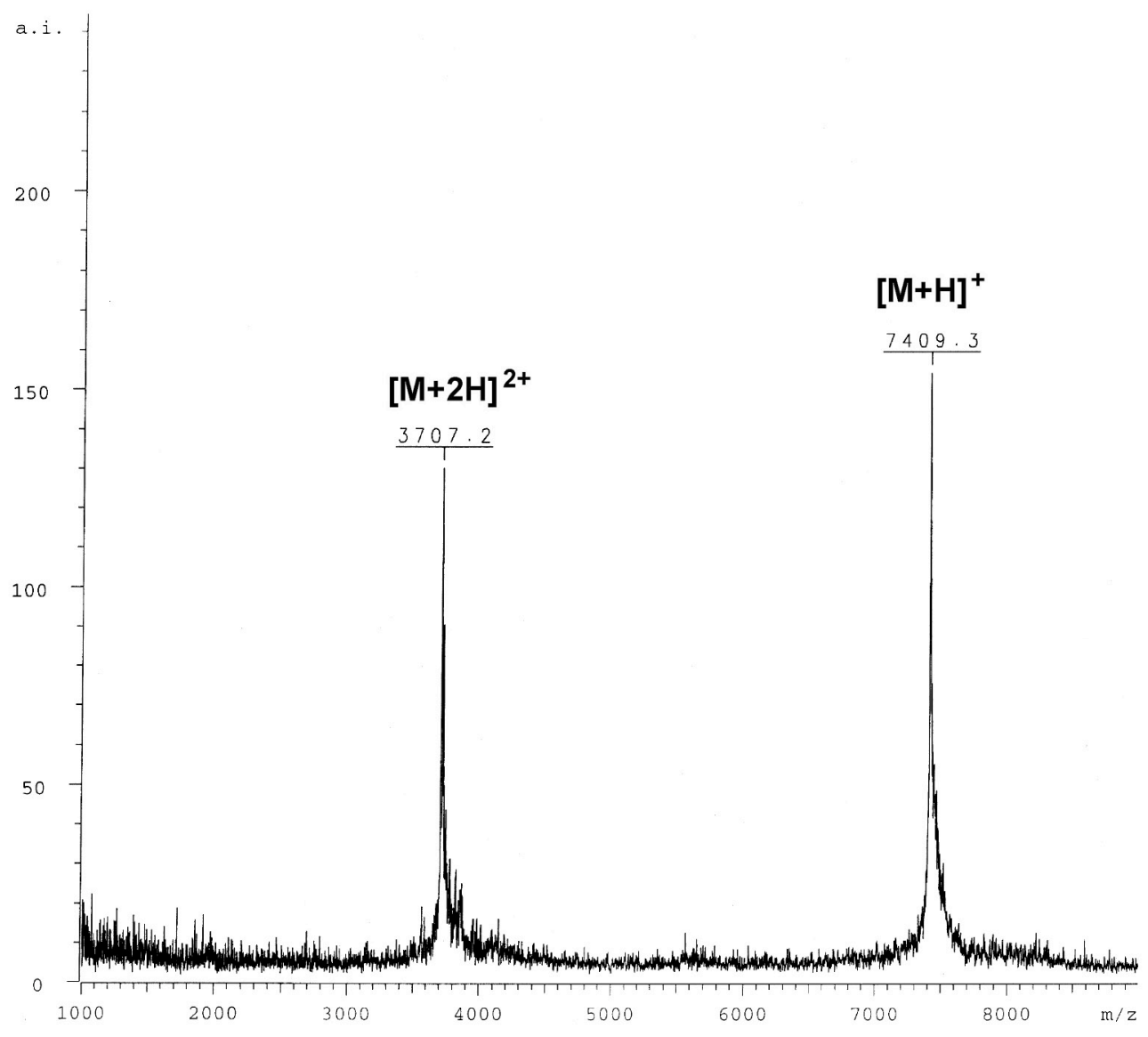


Figure S7. MALDI TOF-MS of purified peptide P1-A1 (calc. $=7758.0\left[\mathrm{M}^{+}\right]$, observed 7765.6). Under the conditions of the MALDI experiment, the disulfide bond cleaves, resulting in the appearance of monomeric A1 (3708.7) and P1 (4049.7) peaks in the mass spectrum.

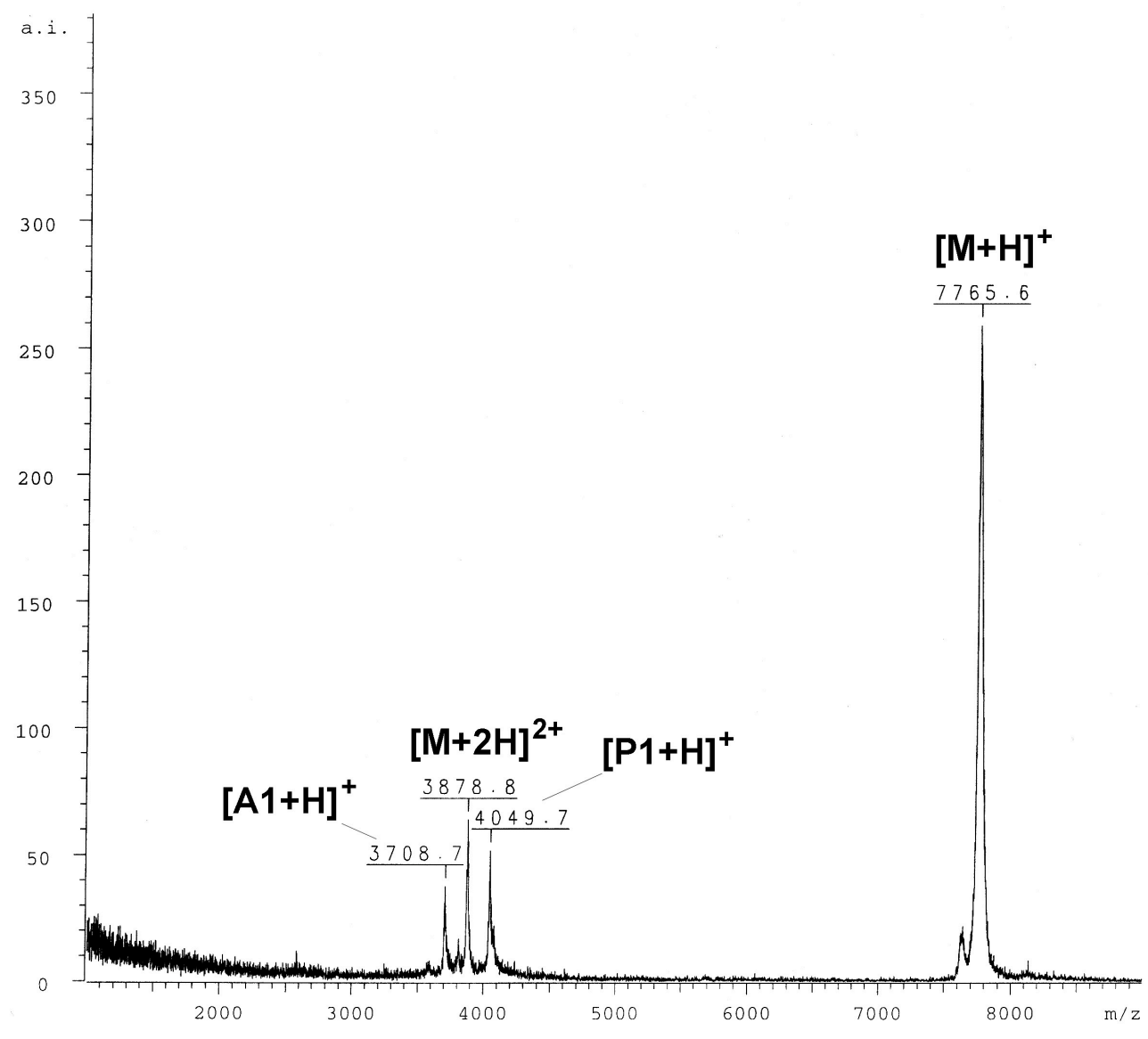


Figure S9. MALDI TOF-MS of purified peptide P2 (calc. $=4260.6[\mathrm{M}+\mathrm{Na}]^{+}$, observed 4260.0). Peptide was in phosphate buffered saline solution $\left(\left[\mathrm{Na}^{+}\right]>137 \mathrm{mM}\right)$.

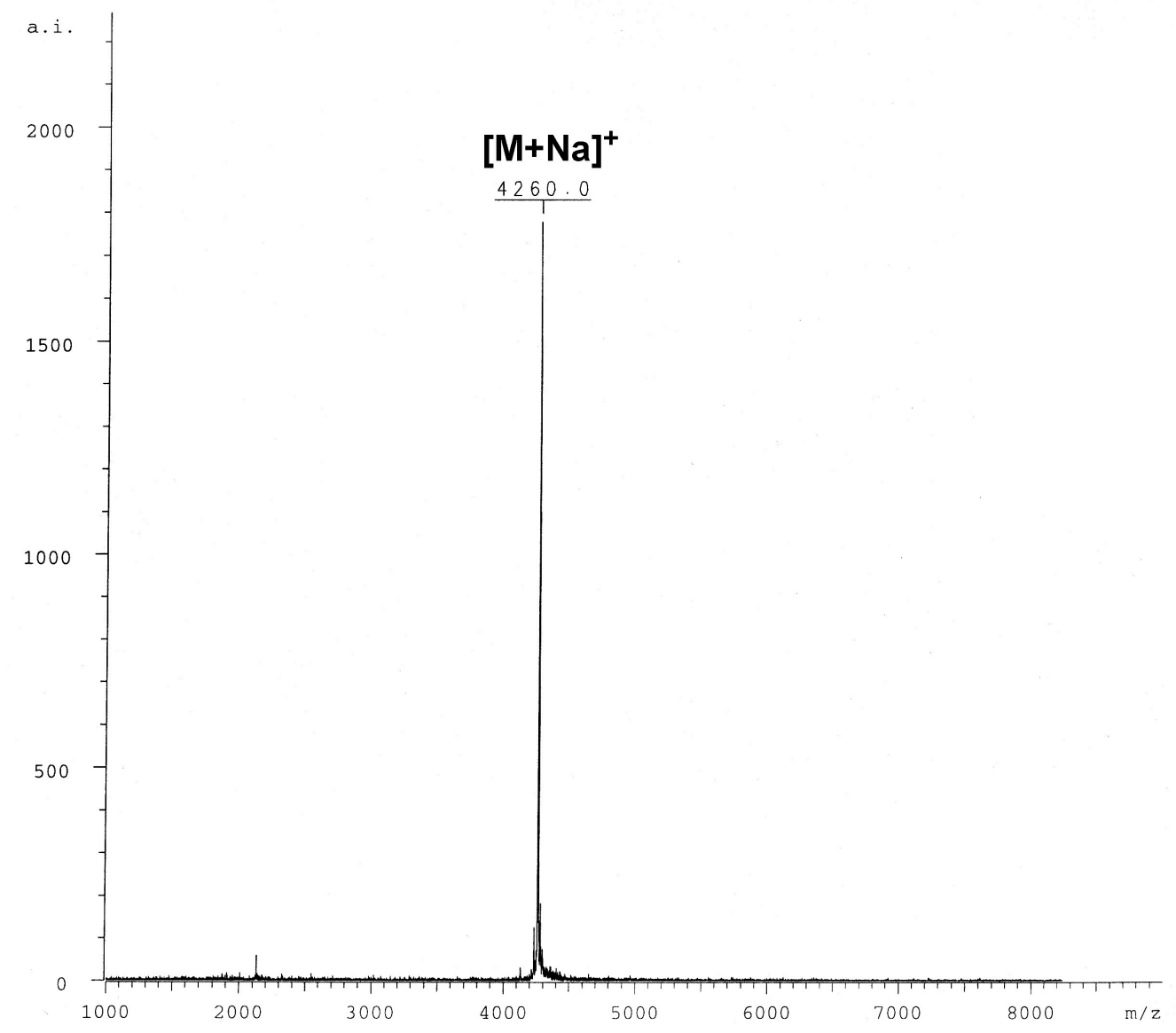

\section{$\underline{\text { References }}$}

(1) Akey, D. L.; Malashkevich, V. N.; Kim, P. S. Biochemistry 2001, 40, 6352-6360.

(2) O'Shea, E. K.; Rutkowski, R.; Kim, P. S. Cell 1992, 68, 699-708. 